\title{
PERBEDAAN ABNORMAL RETURN DAN TRADING VOLUME ACTIVITY SEBELUM DAN SESUDAH PENGUMUMAN RIGHT ISSUE DI BEI
}

\author{
I Gede Andika S Wibawa ${ }^{1}$ \\ Ni Putu Santi Suryantini \\ ${ }^{1,2}$ Fakultas Ekonomi dan Bisnis Universitas Udayana (Unud), Bali, Indonesia \\ email: andikasatriaa28@gmail.com
}

\begin{abstract}
ABSTRAK
Fenomena right issue yang terjadi di Indonesia tahun 2016 dan 2017, terdapat 52 perusahaan yang mengalami right issue dari seluruh sektor perusahaan yang tercatat di Bursa Efek Indonesia, dengan metode non probability sampling dengan teknik pengambilan sampel jenuh. Tujuan penelitian ini adalah untuk mengetahui reaksi pasar pada peristiwa right issue yang diukur dengan abnormal return, abnormal return menurut pengelompokan data ukuran perusahaan, dan volume perdagangan. Pengamatan serta pencatatan data dari laporan-laporan dan arsip-arsip dilakukan untuk pengumpulan data dari beberapa sumber dengan teknik analisis data yaitu uji normalitas dan pengujian hipotesis. Berdasarkan analisis data yang dilakukan pada penelitian mendapatkan hasil bahwa secara parsial pengumuman right issue tidak berdampak signifikan terhadap abnormal return dan abnormal return menurut pengelompokan data ukuran perusahaan. Sedangkan pengumuman right issue memiliki pengaruh signifikan negatif terhadap volume perdagangan. Reaksi negatif investor ditunjukksan dari hal ini akan pengumuman right issue yang dilakukan perusahaan.
\end{abstract}

Kata kunci: right issue, abnormal return, pengelompokan abnormal return menurut ukuran perusahaan, volume perdagangan

\begin{abstract}
The right issue phenomenon that occurred in Indonesia in 2016 and 2017, there were 52 companies that experienced rights issues from all sectors of the company listed on the Indonesia Stock Exchange, with non-probability sampling method with saturated sampling techniques. The purpose of this study was to determine the market reaction in the event of a right issue as measured by abnormal returns, abnormal returns according to the grouping of company size data, and trading volume. Data collection is done by observing and recording data from reports and archives from several sources with data analysis techniques that are normality testing and hypothesis testing. Based on data analysis conducted in the study, it was found that partially the rights issue announcement did not have a significant impact on abnormal returns and abnormal returns according to the grouping of company size data. While the right issue announcement has a significant negative effect on trading volume. This shows that there is a negative reaction from investors regarding the rights issue announcement by the company.
\end{abstract}

Keywords: right issue, abnormal return, abnormal return according to firm size, trading volume activity 
I Gede Andika S Wibawa dan Ni Putu Santi Suryantini, Perbedaan Abnormal Return...

\section{PENDAHULUAN}

Instrumen keuangan perusahaan tidak lepas kaitannya dengan pasar modal. Dalam pasar modal, instumen keuangan yang diperdagangkan seperti warrant, saham, right, reksa dana, obligasi dan instrumen derivatif seperti option, futures dan instrumen derivatif lainnya lainnya. Menurut Undang - Undang Republik Indonesia Nomor 8 tahun 1995 tentang Pasar Modal mendefinisikan pasar modal adalah kegiatan yang bersangkutan dengan penawaran umum dan perdagangan efek, perusahaan publik yang berkaitan dengan efek yang diterbitkannya, serta lembaga dan profesi yang berkaitan dengan efek. Dengan perdagangan instrumen keuangan, pasar modal bertindak sebagai penghubung antara investor dengan perusahaan ataupun institusi pemerintah. Dalam upaya melaksanakan kegiatan investasi tersebut, investor perlu mengambil keputusan investasi.

Banyak perusahaan yang memutuskan untuk mencatatkan sahamnya di pasar modal atau sering disebut go public. Jika perusahaan mencatatkan sahamnya di pasar modal maka melalui penjualan saham kepada publik perusahaan akan memperoleh kesempatan untuk mendapatkan dana. Penjualan saham kepada publik dapat dilakukan dengan aksi korporasi yaitu IPO (initial public offering). IPO adalah penjualan sekuritas perusahaan untuk pertama kali di pasar modal (Tandelilin, 2010:13). Jika perusahaan tersebut memerlukan modal tambahan maka dapat melakukan aksi korporasi yaitu right issue. 


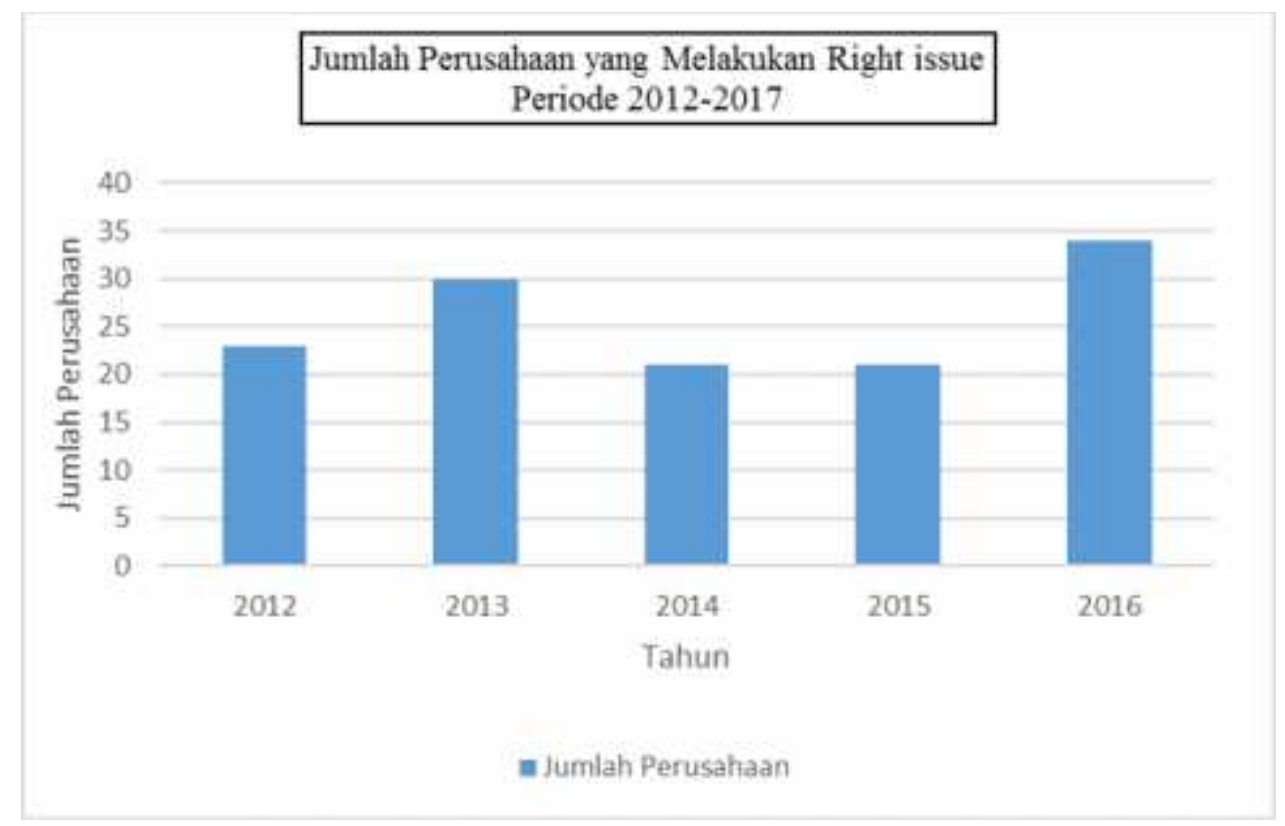

Gambar 1. Perusahaan yang Melakukan Right Issue 2012 - 2016 Sumber: Data diolah, 2018

Berikut merupakan jumlah perusahaan yang melakukan aksi korporasi dari tahun 2012 sampai dengan 2016. Pada tahun 2012 terdapat 23 emiten,lalu pada tahun 2013 terjadi kenaikan yaitu 30 emiten. Pada tahun 2014 dan 2015 terjadi penurunan yaitu 21 emiten yang melaksanakan right issue. Kembali terjadi peningkatan pada tahun 2016 terdapat 34 emiten. Terlihat bahwa pelaksanaan right issue tertinggi tahun 2016 serta terendah tahun 2014 dan 2015.

Berdasarkan data Kustodian Sentral Efek Indonesia Rabu 7 Juni 2017, single investor identification (SID) yang telah mencapai 1.000.289. Jumlah tersebut merupakan jumlah single investor identification yang terdiri dari, surat berharga negara $(\mathrm{SBN})$, surat utang, investor pemilik saham, reksa dana dan efek lain yang tercatat di KSEI. Direktur Utama KSEI, Friderica Widyasari Dewi menuturkan, pencapaian bagi pasar modal Indonesia adalah jumlah investor yang telah melebihi satu juta. Secara menyeluruh, jumlah investor di pasar modal 
I Gede Andika S Wibawa dan Ni Putu Santi Suryantini, Perbedaan Abnormal Return...

mengalami peningkatan 12 persen dari 894.116 pada 2016 menjadi 1.000 .289 per 7 Juni 2017. Dengan peningkatan jumlah investor ini diharapkan dana tersebut dapat ditampung di perusahaan - perusahaan yang baru go public atau yang akan melakukan aksi korporasi right issue. Penawaran umum terbatas alias right issue menjadi salah satu opsi favorit emiten untuk meraup pendanaan dari pasar modal. Mengacu statistik pasar modal Otoritas Jasa Keuangan (OJK), hingga Oktober 2017, nilai rights issue di Bursa Efek Indonesia mencapai Rp 64,33 triliun. Angka ini menanjak 40,83\% dibandingkan periode yang sama tahun lalu, senilai $\mathrm{Rp}$ 45,68 triliun. Analis Binaartha Parama Sekuritas, Reza Priyambada berpendapat, emiten memilih rights issue lantaran prosesnya lebih mudah daripada opsi pendanaan lain. Dia juga mengungkapkan rights issue adalah opsi yang cukup praktis lantaran target investor lebih jelas. Emiten yang akan rights issue hanya dituntut memaparkan penggunaan dana dan rencana aksi korporasi kepada pemegang saham lama.

Nasution (2015) menyatakan pada perusahaan yang go public, nilai perusahaan dilihat dari harga sahamnya. Nilai perusahaan apabila pasar modal dalam keadaan yang efisien dicerminkan oleh harga saham. Pasar yang efisien dapat menunjukkan harga saham yang mencerminkan secara penuh informasi yang tersedia, informasi tersebut dapat berupa , laporan para analis pasar modal, laporan tahunan perusahaan, pemecahan saham, pembagian deviden, dan sebagainya. Pasar efisien terdiri dari tiga jenis, ketiga bentuk pasar efisien dimaksud adalah (1) efisiensi pasar bentuk lemah (weak form), (2) efisiensi pasar 
bentuk setengah kuat (semi strong form), dan efisiensi bentuk kuat (strong form) (Hartono, 2015:586).

Salah satu aksi korporasi dan informasi yang dapat digunakan untuk menilai efisiensi pasar adalah aksi korporasi right issue. Perubahan harga saham yang menggambarkan terdapatnya reaksi pasar pada saat pengumuman aksi korporasi yang akan mengakibatkan abnormal return. Abnormal return atau excess return merupakan kelebihan return yang sesungguhnya terjadi terhadap return yang normal (Hartono, 2015:647).

Pengumuman right issue adalah salah satu informasi corporate action yang dipublikasikan oleh perusahaan emiten. Melalui pengumuman right issue perusahaan dapat mengetahui ada atau tidaknya reaksi dari pasar. Ketika pengumuman right issue tersebut dirasa mengandung informasi yang penting, maka akan adanya return saham yang merupakan salah satu bentuk pasar bereaksi terhadap pengumuman tersebut. Putri dkk. (2016) semakin besar nilai dari return saham menunjukan kinerja perusahaan yang semakin baik dan kepercayaan masyarakat yang semakin tinggi kepada perusahaan tersebut.

Rusnanda dan Pardi (2013) menyatakan abnormal return adalah return yang didapat pemegang saham tidak sesuai dengan pengharapan. Abnormal return adalah selisih antara return yang diharapkan dengan return yang. Selisih return tersebut positif jika didapatkan return yang lebih besar dari return yang diharapkan. Sedangkan return tersebut negatif jika didapatkan return yang lebih kecil dari return yang diharapkan. Beberapa kejadian yang mampu menyebabkan abnormal return pada saham suatu perusahaan emiten misalnya hari libur, 
I Gede Andika S Wibawa dan Ni Putu Santi Suryantini, Perbedaan Abnormal Return...

diterbitkan regulasi baru, awal bulan, kebijakan baru, hal politik yang tidak pasti, dan pelaksanaan aksi korporasi seperti, stock split, penawaran perdana saham, dan peristiwa lainnya yang dapat mempengaruhi harapan investor.

Beberapa penelitian sebelumnya menyebutkan bahwa right issue memiliki kandungan informasi yang menyebabkan adana reaksi dari pasar,tetap didapatkan hasil yang berbeda pada penelitian lain. Beberapa penelitian sebelumnya menyebutkan bahwa right issue memiliki informasi yang membuat pasar bereaksi di antaranya-; Epriyeni (2012) menyatakan pengumuman right issue memiliki pengaruh terhadap abnormal return saham, Kabir dan Roosenboom (2012) mengungkapkan bahwa harga saham menurun secara signifikan pada pengumuman right issue, ini menunjukkan bahwa pemegang saham menafsirkan masalah hak ekuitas sebagai berita negatif, Kithinji et al. (2014) ada reaksi positif terhadap pengumuman aksi korporasi right issue dan faktor eksternal tersebut mempengaruhi reaksi dari pasar terhadap pengumuman, Edirisinghe and Nimal (2015) terdapat reaksi yang signifikan dari harga saham di pasar saat pengumuman right issue, dan menurut Umesh et al. (2016) terdapat average abnormal return yang positif pada waktu pengumuman aksi korporasi right issue yang menunjukan terdapatnya reaksi pasar akan pengumuman itu.

Kontradiksi dengan penelitian yang mengatakan pengumuman right issue tidak memiliki informasi yang membuat pasar beraksi di antaranya-; Mohanty (2012) menyatakan bahwa tidak ada dari rights issue di India, Jayanti (2014) Tidak didapatkan perbedaan sebelum dan sesudah pengumuman right issue pada abnormal return, dan Kithinji et al. (2014) bahwa pengumuman rights issue tidak 
memliki pengaruh terhadap reaksi investor, Otieno (2015) pengumuman right issue tidak memiliki pengaruh terhadap return saham dari suatu perusahaan, Pratama (2015) bahwa tidak ada perbedaan yang signifikan abnormal return sebelum maupun sesudah peristiwa right issue. Penelitian ini mengembangkan penelitian Artayasa (2017) dengan melakukan pengelompokkan data menurut ukuran perusahaan dan volume perdagangan.

Ukuran perusahaan adalah menggambarkan besar kecilnya suatu perusahaan. Ukuran perusahaan yang menunjukkan besar kecilnya perusahaan dapat dilihat total aktiva yang dimiliki, besar kecilnya modal yang digunakan, atau total penjualan yang diperoleh (Andayani, 2015). Adapun ukuran perusahaan Ang (2001), mengacu pada kapitalisasi pasar perusahaan tersebut dapat dikatagorikan menjadi tiga yaitu perusahaan besar, menengah dan kecil.

Agustin (2017) menyatakan volume perdagangan saham atau trading volume activity adalah jumlah adalah perbandingan antara jumlah saham yang diperdagangkan pada waktu tertentu dengan jumlah saham sebuah perusahaan yang beredar dalam periode tertentu. Jayanti (2014) menyatakan jika terdapat perubahan dari volume perdagangan saham maka pengumuman right issue mengandung informasi. Sebaliknya, jika tidak terdapat perubahan dari volume perdagangan saham maka pengumuman right issue tidak mengandung informasi.

Berdasarkan ketidakkonsistenan temuan empiris pada penelitian sebelumnya maka diperlukan penelitian lebih lanjut. Penelitian ini diharapkan dapat memberikan penjelasan yang lebih rinci dengan mempertimbangkan volume perdagangan sebagai dasar pengelompokan perusahaan. Adapun kerangka 
I Gede Andika S Wibawa dan Ni Putu Santi Suryantini, Perbedaan Abnormal Return...

konseptual dalam penelitian ini menunjukkan pengaruh antar variabel dalam penelitian. Kerangka konseptual dalam penelitian ini disajikan dalam gambar 2 sebagai berikut.

1. Abnormal return

2. Abnormal return menurut ukuran perusahaan

3. Volume perdagangan

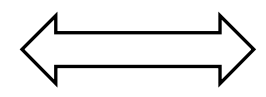

1. Abnormal return

2. Abnormal return menurut ukuran perusahaan 3. Volume perdagangan

\section{Gambar 2. Kerangka Konseptual}

Sumber : Data diolah, 2018

Kerangka konseptual ini menjelaskan abnormal return, abnormal return menurut ukuran perusahaan, serta volume perdagangan sebelum dan sesudah right issue. Tujuannya adalah untuk melihat apakah terdapat perbedaan signifikan abnormal return sebelum dan sesudah right issue dengan menggunakan teknik paired sample t-test.

Degustis dan Lina (2015) menyatakan pasar yang efisien atau efficient market adalah pasar dimana harga saham mencerminkan informasi mendasar tentang perusahaan. Perbandingan antara harga saham di pasar dan nilai intrinsik saham mencerminkan tingkat efisiensi pasar (Samsul, 2006:270).

Hendrianto (2015) menyatakan teori sinyal menjelaskan mengapa perusahaan mempunyai dorongan untuk memberikan informasi keuangan kepada pihak eksternal. Akan terdapat respon positif jika pengumuman tersebut mengandung berita yang baik serta terdapat abnormal return yang positif untuk mencerminkan pengumuman tersebut sedangkan akan terdapat respon yang 
negatif dari pasar apabila pengumuman tersebut mengandung berita yang buruk serta terdapat abnormal return yang negatif mencerminkan pengumuman tersebut (Tandelilin, 2010:565).

Menurut Oktavia (2015) event study merupakan suatu penelitian yang menggambarkan sebuah tehnik penelitian untuk melihat dampak suatu peristiwa tertentu terhadap perubahan dimensi atau variabel. Menurut Kisworo (2011) Event study dapat digunakan untuk menguji kandungan informasi dari suatu pengumuman dalam hal ini right issue yang berupa reaksi dapat digunakan untuk menguji efisiensi pasar setengah kuat.

Manajemen suatu perusahaan memiliki informasi yang akurat mengenai perusahaan, pada saat manajemen suatu perusahaan melakukan penyampaian informasi kepada publik maka informasi yang disampaikan tersebut akan menyebabkan pasar bereaksi karena informasi tersebut merupakan suatu sinyal. Abnormal return yang positif menunjukkan berita baik direspon positif oleh investor Begitu juga dengan berita buruk akan menghasilkan abnormal return yang negatif karena mendapatkan respon yang negatif dari investor (Tandelilin, 2010:565). ketersediaan informasi yang berkualitas sangat diperlukan pada pasar modal untuk keputusan investasi (Dewi, 2013). Dengan informasi yang berkualitas serta relevan, pasar memiliki gambaran terhadap return yang diekspetasikan atas modal yang telah diinvestasikan pada suatu perusahaan karena mereka dapat menilai prospek kinerja emiten tersebut (Zaqi, 2006). Informasi mengenai pengumuman aksi korporasi right issue merupakan informasi penting bagi pasar, ini ditunjukkan dengan terdapatnya abnormal return pada sekitar 
I Gede Andika S Wibawa dan Ni Putu Santi Suryantini, Perbedaan Abnormal Return...

tanggal informasi aksi korporasi right issue diumumkan (Nisak, 2015). Berdasarkan pemaparan tersebut, maka muncul hipotesis, yaitu:

$\mathrm{H}_{1}$ : Terdapat perbedaan abnormal return sebelum dan sesudah pengumuman right issue

Ukuran perusahaan menunjukkan besar atau kecilnya suatu perusahaan yang dapat dilihat dari jumlah ekuitas, tingkat penjualan, atau jumlah aktiva yang dimiliki oleh suatu perusahaan beserta kapitalisasi suatu pasar saham. Semakin besar perusahaan, biasanya informasi yang disediakan untuk investor dalam pengambilan keputusan yang berhubungan dengan investasi dalam saham perusahaan tersebut semakin lengkap (Hendrayanti, 2013). Ukuran perusahaan yang besar menunjukkan perusahaan mengalami perkembangan sehingga terdapat respon yang positif dari investor dan nilai perusahaan akan meningkat (Munawaroh,2013). Berdasarkan pemaparan tersebut, maka muncul hipotesis yaitu:

$\mathrm{H}_{2}$ : Pada perusahaan kecil, sedang dan besar didapatkan perbedaan abnormal return sebelum dan sesudah pengumuman right issue

Saham dengan frekuensi perdagangan yang besar dapat dipengaruhi sangat aktifnya transaksi saham, hal ini dapat terjadi karena banyaknya minat investor akan saham tersebut. Frekuensi dari transaksi perdagangan meningkat ditandai harga saham akan meningkat karena permintaan yang tinggi di pasar sehingga return dari saham juga akan meningkat. Dalam aktivitas pasar modal ataupun bursa efek, jumlah dari perdagangan saham adalah salah satu aktivitas yang dapat digunakan untuk melihat terdapat reaksi atau tidak dari pasar terhadap sebuah informasi yang terdapat pada pasar modal (Silviyani dkk., 2014). Volume 
perdagangan adalah suatu parameter likuiditas saham akan terdapatnya atau tidak informasi pada pasar modal. Magdelena (2004) menyatakan Volume perdagangan saham adalah jumlah lembar saham yang diperdagangkan secara harian Penelitian yang dilakukan oleh Omran dan Eric (2009) menyatakan tentang keterkaitan volume perdagangan yang ditunjukkan dari tingkat pengembalian saham terdapatnya hubungan antara volume perdagangan dan tingkat pengembaliaan saham. Berdasarkan pemaparan tersebut, maka muncul hipotesis yaitu:

$\mathrm{H}_{3}$ : Terdapat perbedaan volume perdagangan sebelum dan sesudah pengumuman right issue.

\section{METODE PENELITIAN}

Penelitian ini adalah event study mengenai perbedaan abnormal return dan trading volume activity sebelum dan sesudah right issue. Penelitian bertujuan untuk melihat pengaruh right issue terhadap ada reaksi atau tidak dari pasar. Teori - teori yang digunakan dalam literatur penelitian berasal dari buku - buku ilmiah, jurnal, tulisan ilmiah (skripsi, tesis, artikel). Penelitian ini menggunakan pendekatan kuantitatif dengan mengalisis reaksi pasar terhadap perusahaan yang melakukan right issue pada periode 2016 dan 2017.

Pengujian pertama menggunakan sampel keseluruhan. Pengujian kedua menggunakan pengelompokkan sampel berdasarkan ukuran perusahaan yang dikatagorikan berdasarkan kapitalisasi pasarnya yakni, perusahaan besar, perusahaan sedang, dan perusahaan kecil. Pengujian ketiga menggunakan pengelompokan sampel berdasarkan volume perdagangan yang menggunakan perbandingan tingkat kenaikan jumlah lembar saham yang diperdagangkan 
I Gede Andika S Wibawa dan Ni Putu Santi Suryantini, Perbedaan Abnormal Return...

perusahaan tahun sebelum dengan tahun saat melakukan right issue. Berdasarkan pemaparan peneliti, desain penelitian dapat dilihat seperti pada gambar 3.

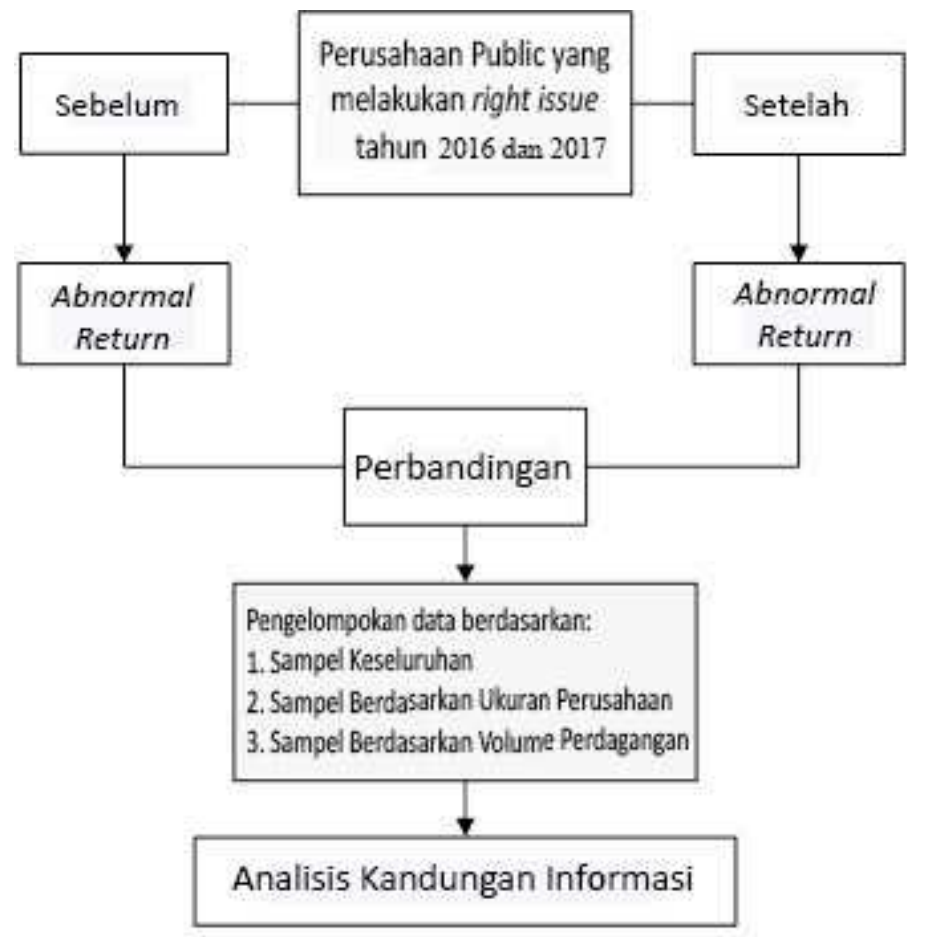

\section{Gambar 3. Desain Penelitian}

Sumber: Data diolah, 2018.

.Variabel-variabel yang terdapat dalam penelitian ini adalah Abnormal return adalah pengukuran variable dengan mengurangi return yang terjadi dengan return ekspektasian (Hartono, 2015:580). Market adjusted model digunakan dalam penelitian ini untuk mengestimasi return ekspektasinya.

Pertama dilakukan perhitungan return yang sesungguhnya (actual return) masingmasing sampel (Hartono, 2015;265) :

$$
\mathrm{R}_{\mathrm{it}}=\frac{p_{\mathrm{t}}-p_{\mathrm{t}-1}}{r_{\mathrm{t}-1}}
$$

\section{Keterangan:}

Rit :return individual saham i pada saat $\mathrm{t}$

$\mathrm{Pt}$ : harga penutupan saham i pada saat $\mathrm{t}$ 
E-Jurnal Manajemen, Vol. 8, No. 4, 2019: 2381 - 2408

Pt-1 : harga penutupan saham i pada saat t-1

Kedua, perhitungan return pasar harian (Hartono,2015:648) :

$$
\mathrm{Rm}_{\mathrm{t}}=\frac{l H S G_{t}-l H S G_{t-\mathrm{I}}}{l H S G_{t-1}}
$$

Keterangan:

Rmt : tingkat return pasar pada saat $\mathrm{t}$

IHSGt : Indeks Harga Saham Gabungan pada saat t

IHSGt-1 : Indeks Harga Saham Gabungan pada saat t-1

Ketiga, perhitungan abnormal return masing-masing sampel dengan rumus:

$$
\text { Ari,t }=R_{i t}-R m_{t}
$$

Keterangan:

ARt : abnormal return saham i saat $\mathrm{t}$

Rit : return individual saham i saat $\mathrm{t}$

Rmt : tingkat return saham saat $\mathrm{t}$

Penggunaan model ini tidak dilakukan pada tiap sekuritas tetapi dilakukan secara komposit dengan melakukan pengujian dari Cumulative abnormal return tiap saham, metode cross section digunakan untuk tiap hari di periode peristiwa (Hartono, 2015:328)

Keempat, melakukan perhitungan Cumulative abnormal return yaitu:

$$
\mathrm{CAR}_{\mathrm{t}}=\sum_{a=t 1}^{t=5} A R_{i t}
$$

Keterangan:

CARit: Cumulative abnormal return perusahaan ke i perioda $\mathrm{t}$, yang diakumulasi dari ARit sekuritas ke-i, periode peristiwa sebelum (t-5) sampai (t-1) dan periode peristiwa setelah $(\mathrm{t}+1)$ sampai $(\mathrm{t}+5)$ 
I Gede Andika S Wibawa dan Ni Putu Santi Suryantini, Perbedaan Abnormal Return...

Selanjutnya melakukan perhitungan Trading Volume Activity, dapat dilakukan dengan melakukan perbandingan jumlah saham perusahaan yang diperdagangkan pada periode penelitian dengan jumlah saham beredar keseluruhan dari emiten tersebut pada kala waktu yang sama. Rumus yang dapat digunakan sebagai berikut:

$\mathrm{TVA}_{\mathrm{i}, \mathrm{t}}=\frac{2 \text { Saham yury diperdagang kan pada waktu } t}{2 \text { Saham yung beredar pada waktu } t}$

Data sekunder digunakan dalam penelitian ini sebagai sumber data yaitu data yang diperoleh secara tidak langsung melalui media perantara (Sugiyono, 2013:129). . Adapun data tersebut didapat dari perusahaan yang terdaftar di Bursa Efek Indonesia dengan mengunjungi website www.idx.co.id, website yahoo finance, dan Indonesian Capital Market Directory.

Populasi pada penelitian adalah semua perusahaan yang terdaftar di Bursa Efek Indonesia yang melakukan right issue pada periode 2015 - 2017. Populasi perusahaan tersebut sebanyak 52 perusahaan. Teknik sampling pada penelitian ini adalah non probability sampling yang menggunakan metode penentuan sampel jenuh. Metode sampel jenuh adalah teknik penentuan sampel bila semua anggota populasi digunakan menjadi sampel, sehingga sampel pada penelitian ini adalah semua perusahaan yang terdaftar di Bursa Efek Indonesia yang melakukan right issue pada periode 2016 dan 2017 sebanyak 52 perusahaan.

\section{HASIL DAN PEMBAHASAN}

Penelitian ini menggunakan sampel perusahaan terbuka yang melakukan aksi korporasi perusahaan yaitu right issue dan terdaftar di Bursa Efek Indonesia pada tahun 2016 dan 2017 dan sampel bergerak pada seluruh sektor tanpa ada 
membatasi jenis sektor entitas yang diteliti. Dalam pemilihan sampelnya, penelitian ini menggunakan metode sampel jenuh pada saat seluruh anggota populasi masuk sebagai sampel, sehingga pada penelitiaan ini sampelnya adalah semua perusahaan yang terdaftar di Bursa Efek Indonesia yang melakukan right issue pada periode 2016 dan 2017 sebanyak 52 perusahaan.

Studi peristiwa ini menggunakan amatan 5 hari sebelum dan hari sesudah pengumuman aksi korporasi right issue. Tanggal pengumuman right issue merupakan $\mathrm{t}(0)$. Data yang digunakan dalam perhitungan abnormal return adalah return realisasi dan return pasar. Pembandingan abnormal return sebelum dan sesudah peristiwa untuk melihat signifikansi ada atau tidak reaksi dari pasar saat pengumuman aksi korporasi tersebut

Hipotesis 1 sampel akan diuji secara keseluruhan, hipotesis 2 sampel akan dikelompokkan sesuai ukuran perusahaan dan hipotesis 3 data akan disesuaikan dengan volume perdagangan perusahaan.

Hasil analisis deskriptif yang akan diuji adalah keseluruhan sampel penelitian yang berjumlah 52 , sampel perusahaan besar yang berjumlah 24, sampel perusahaan sedang yang berjumlah 18, sampel perusahaan kecil yang berjumlah 10, dan seluruh sampel volume perdagangan yang berjumlah 52 . Hasil analisis deskriptif 52 sampel keseluruhan dapat dilihat pada tabel 1.

Berdasarkan Tabel 1 Nilai rata - rata CAR sebelum adalah sebesar 0,002492 nilai standar deviasi sebesar 0,062859. Rata - rata nilai tersebut negatif, hal ini berarti bahwa selama 5 hari sebelum pengumuman pasar cenderung memiliki reaksi negatif dalam pembelian saham perusahaan. Nilai minimum dari 
I Gede Andika S Wibawa dan Ni Putu Santi Suryantini, Perbedaan Abnormal Return...

CAR adalah sebesar $-0,156466$ dan nilai maksimum dari CAR adalah sebesar 0,185826 .

Tabel 1.

Statistik Deskriptif Keseluruhan

\begin{tabular}{lcrrrr}
\hline Variabel & Jumlah & \multicolumn{1}{c}{ Minimum } & Maksimum & Rata-Rata & \multicolumn{1}{l}{$\begin{array}{l}\text { Std. } \\
\text { Deviation }\end{array}$} \\
\hline CAR Sebelum & 52 & $-0,156466$ & 0,185826 & $-0,002492$ & 0,062859 \\
CAR Sesudah & 52 & $-0,206373$ & 0,242235 & $-0,012039$ & 0,072134
\end{tabular}

Sumber : Data diolah dengan IBM SPSS Statistics 23

Nilai rata - rata CAR sebelum adalah sebesar -0,012039 dengan standar deviasi (SD) sebesar 0,072134. Nilai tersebut memiliki rata-rata negatif, hal ini berarti bahwa selama 5 hari sesudah pengumuman pasar cenderung memiliki reaksi negatif dalam pembelian saham perusahaan. Nilai minimum dari CAR adalah sebesar -0,206373 dan nilai maksimum dari CAR adalah sebesar 0,242235. Hasil analisis deskriptif 24 perusahaan besar dapat dilihat pada tabel 2.

\section{Tabel 2.}

Statistik Deskriptif Perusahaan Besar

\begin{tabular}{lccccc} 
Variabel & Jumlah & Minimum & Maksimum & Rata-Rata & \multicolumn{1}{l}{$\begin{array}{l}\text { Std. } \\
\text { Deviation }\end{array}$} \\
\hline CAR Sebelum & 24 & $-0,156466$ & 0,124766 & $-0,012970$ & 0,063109 \\
CAR Sesudah & 24 & $-0,131219$ & 0,242235 & 0,011064 & 0,068758
\end{tabular}

Sumber : Data diolah dengan IBM SPSS Statistics 23

Berdasarkan Tabel 2 Nilai rata - rata CAR sebelum adalah sebesar 0,012970 nilai standar deviasi (SD) sebesar 0,063109. Nilai tersebut memiliki rata-rata negatif, hal ini berarti bahwa selama 5 hari sebelum pengumuman pasar cenderung memiliki reaksi negatif dalam pembelian saham perusahaan. Nilai minimum dari CAR adalah sebesar -0,156466 dan nilai maksimum dari CAR adalah sebesar 0,124766 . 
Nilai rata - rata CAR sebelum adalah sebesar 0,011064 nilai standar deviasi (SD) sebesar 0,068758. Nilai tersebut memiliki rata-rata positif, hal ini berarti bahwa selama 5 hari sesudah pengumuman pasar cenderung memiliki reaksi positif dalam pembelian saham perusahaan. Nilai minimum dari CAR adalah sebesar -0,131219 dan nilai maksimum dari CAR adalah sebesar 0,242235.

Hasil analisis deskriptif 18 perusahaan menengah dapat dilihat pada tabel 3.

Tabel 3.

Statistik Deskriptif Perusahaan Menengah

\begin{tabular}{lcccccc} 
Variabel & Jumlah & Minimum & Maksimum & Rata-Rata & \multicolumn{1}{l}{$\begin{array}{l}\text { Std. } \\
\text { Deviation }\end{array}$} \\
\hline CAR Sebelum & 18 & $-0,110967$ & 0,166242 & $-0,000908$ & 0,058395 \\
CAR Sesudah & 18 & $-0,182654$ & 0,081842 & $-0,031032$ & 0,069390
\end{tabular}

Sumber : Data diolah dengan IBM SPSS Statistics 23

Berdasarkan Tabel 3 Nilai rata - rata CAR sebelum adalah sebesar 0,0009084 nilai dari standar deviasi (SD) sebesar 0,058395. Nilai tersebut memiliki rata-rata negative, hal ini berarti bahwa selama 5 hari sebelum pengumuman pasar cenderung memiliki reaksi negatif dalam pembelian saham perusahaan. Nilai minimum dari CAR adalah sebesar $-0,110967$ dan nilai maksimum dari CAR adalah sebesar 0,166242

Nilai rata - rata CAR sebelum adalah sebesar -0,031032 nilai dari standar deviasi (SD) sebesar 0,069390. Nilai tersebut memiliki rata-rata negatif, hal ini berarti bahwa selama 5 hari sesudah pengumuman pasar cenderung memiliki reaksi negatif dalam pembelian saham perusahaan. Nilai minimum dari CAR adalah sebesar -0,182654 dan nilai maksimum dari CAR adalah sebesar 0,081842. 
I Gede Andika S Wibawa dan Ni Putu Santi Suryantini, Perbedaan Abnormal Return...

Tabel 4.

Statistik Deskriptif Sampel Perusahaan Kecil

\begin{tabular}{lcrrrr} 
Variabel & Jumlah & Minimum & Maksimum & Rata-Rata & \multicolumn{1}{l}{$\begin{array}{l}\text { Std. } \\
\text { Deviation }\end{array}$} \\
\hline CAR Sebelum & 10 & $-0,049898$ & 0,185826 & $-0,019803$ & 0,070153 \\
CAR Sesudah & 10 & $-0,206373$ & 0,038676 & $-0,033302$ & 0,075243
\end{tabular}

Sumber : Data diolah dengan IBM SPSS Statistics 23

Berdasarkan Tabel 4 Nilai rata - rata CAR sebelum adalah sebesar 0,019803 nilai dari standar deviasi (SD) sebesar 0,070153. Nilai tersebut memiliki rata-rata negatif, hal ini berarti bahwa selama 5 hari sebelum pengumuman pasar cenderung memiliki reaksi negatif dalam pembelian saham perusahaan. Nilai minimum dari CAR adalah sebesar -0,049898 dan nilai maksimum dari CAR adalah sebesar 0,185826 .

Nilai rata - rata CAR sebelum adalah sebesar -0,033302 nilai dari standar deviasi (SD) sebesar 0,075243 . Nilai tersebut memiliki rata-rata negatif, hal ini berarti bahwa selama 5 hari sesudah pengumuman pasar cenderung memiliki reaksi negatif dalam pembelian saham perusahaan. Nilai minimum dari CAR adalah sebesar -0,206373 dan nilai maksimum dari CAR adalah sebesar 0,038676.

Tabel 5.

\begin{tabular}{lccccc}
\multicolumn{7}{c}{ Statistik Deskriptif Trading Volume Activity } & \\
\hline Variabel & Jumlah & \multicolumn{1}{l}{ Minimum } & \multicolumn{1}{l}{ Maksimum } & \multicolumn{1}{l}{ Rata-Rata } & \multicolumn{1}{l}{$\begin{array}{l}\text { Std. } \\
\text { Deviation }\end{array}$} \\
\hline TVA Sebelum & 52 & 0,000000 & 0,165414 & 0,013108 & 0,028282 \\
TVA Sesudah & 52 & 0,000000 & 0,096372 & 0,007664 & 0,015615
\end{tabular}

Sumber : Data diolah dengan IBM SPSS Statistics 23

Berdasarkan Tabel 5 Nilai rata - rata trading volume activity sebelum adalah sebesar 0,013108 dengan standar deviasi (SD) sebesar 0,028282. Nilai rata rata lebih kecil dari standar deviasi menunjukkan kesenjangan data satu dengan 
data lainnya jauh. Nilai minimum TVA adalah sebesar 0,000000 dan nilai maksimum dari TVA adalah sebesar 0,165414.

Nilai rata - rata trading volume activity sebelum adalah sebesar 0,007664 nilai dari standar deviasi (SD) sebesar 0,015615. Nilai Nilai rata rata lebih kecil dari standar deviasi menunjukkan kesenjangan data satu dengan data lainnya jauh. Nilai minimum TVA adalah sebesar 0,000000 dan nilai maksimum TVA adalah sebesar 0,096372 .

Hasil uji statistik pada penelitian ini menggunakan alat bantu IBM SPSS Statistics 23, yang dirangkum pada tabel 6

Tabel 6.

Rangkuman Hasil Uji Statistik Keseluruhan

\begin{tabular}{ccccc}
\hline Hipotesis & $\begin{array}{c}\text { Jumlah } \\
\text { Sampel }\end{array}$ & Rata-Rata & $\begin{array}{c}\text { Sig (2-Tailed)/ } \\
\text { Asymp. Sig. (2-tailed) }\end{array}$ & Keterangan \\
\hline $\mathbf{H}_{\mathbf{1}}$ & 52 & $-0,002492$ & 0,531 & $\begin{array}{c}\text { Tidak } \\
\text { Signifikan }\end{array}$ \\
\cline { 2 - 4 } $\mathbf{H}_{2} \mathbf{a}$ & 52 & $-0,012039$ & & Tidak \\
& 24 & $-0,012970$ & 0,0272 & Signifikan \\
\hline $\mathbf{H}_{2} \mathbf{b}$ & 24 & 0,011064 & & Tidak \\
& 18 & $-0,000908$ & 0,262 & Signifikan \\
\hline $\mathbf{H}_{2} \mathbf{c}$ & 18 & $-0,031032$ & & Tidak \\
& 10 & $-0,019803$ & 0,139 & Signifikan \\
\hline $\mathbf{H}_{3} \mathbf{a}$ & 10 & $-0,033302$ & & Signifikan \\
& 52 & 0,013108 & 0,009 & \\
\hline
\end{tabular}

Sumber : Data diolah dengan IBM SPSS Statistics 23

Pembahasan $\mathrm{H}_{1}$ sampel keseluruhan, hasil dari pengujian menunjukan pada periode sebelum dan sesudah pengumuman right issue tidak didapatkan perbedaan dari abnormal return. Hasil ini sesuai dengan hipotesis $1\left(\mathrm{H}_{1}\right)$. Hasil hipotesis ini didukung beberapa teori, yaitu teori pasar efisien dan teori sinyal. Informasi mengenai dari aksi korporasi right issue ini telah membuat pasar bereaksi akan karena ada sinyal dari informasi tersebut. 
I Gede Andika S Wibawa dan Ni Putu Santi Suryantini, Perbedaan Abnormal Return...

Cumulative abnormal return (CAR) sebelum memiliki rata-rata sebesar 0,002492 dan Cumulative abnormal return (CAR) sesudah memiliki rata-rata sebesar -0,012039, hasil ini membuktikan bahwa nilai CAR sebelum lebih tinggi daripada CAR sesudah. Peningkatan abnormal return setelah pengumuman aksi korporasi right issue tidak signifikan karena pasar menganggap informasi right issue mengandung informasi negatif untuk perusahaan tersebut. Hal ini menunjukkan bahwa pasar telah mengantisipasi adanya informasi yang masuk ke pasar, dan informasi yang dipublikasikan tersebut belum mampu mempengaruhi harga saham secara keseluruhan. Sedangkan abnormal return yang negatif dapat terjadi karena adanya penyesuaian harga yang disebabkan oleh aksi korporasi lainnya.

Beberapa penelitian mendapatkan hasil yang sama Mohanty (2012) menyatakan bahwa tidak ada efek pengumuman yang signifikan dari rights issue di India, Jayanti (2014) Sebelum dan sesudah pengumuman right issue tidak didapatkan adanya perbedaan abnormal return, dan Kithinji et al. (2014) bahwa pengumuman rights issue tidak berdampak signifikan terhadap reaksi investor.

Pembahasan $\mathrm{H}_{2}$ (CAR sampel perusahaan besar, sedang, kecil) Hasil Pengujian menunjukan sebelum dan sesudah pengumuman right issue tidak didapatkan adanya perbedaan abnormal return pada perusahaan besar, sedang, dan kecil. Hasil pengujian ini tidak sesuai dengan hipotesis $2\left(\mathrm{H}_{2}\right)$. Hal ini dapat terjadi karena informasi right issue telah diketahui investor sebelum pengumuman aksi korporasi tersebut atau dapat dikatakan terjadi kebocoran informasi. 
Cumulative abnormal return (CAR) perusahaan besar sebelum memiliki rata-rata sebesar -0,012970 dan Cumulative abnormal return (CAR) perusahaan besar sesudah memiliki rata-rata sebesar 0,011064. Cumulative abnormal return (CAR) perusahaan sedang sebelum memiliki rata-rata sebesar $-0,000908$ dan Cumulative abnormal return (CAR) perusahaan sedang sesudah memiliki ratarata sebesar -0,031032. Cumulative abnormal return (CAR) perusahaan kecil sebelum memiliki rata-rata sebesar -0,019803 dan Cumulative abnormal return (CAR) perusahaan kecil sesudah memiliki rata-rata sebesar -0,033302, hasil ini menunjukkan nilai CAR terjadi kenaikan maupun penurunan CAR sebelum dengan CAR sesudah. Kenaikan dan penurunan abnormal return sebelum dan sesudah pengumuman aksi korporasi perusahaan emiten right issue pada pengelompokan data berdasarkan ukuran perusahaan tidak signifikan.

Beberapa penelitian mendapatkan hasil yang sama Anggaraini dan Suprasto (2015) dimana ukuran perusahaan tidak menghasilkan pengaruh terhadap reaksi pasar. Menurut Asmara (2017) ukuran perusahaan dianggap tidak cukup informatif dan tidak lagí menjadi perhatian investor dalam mengambíl keputusan berinvestasi serta tidak dapat digunakan untuk mengestimasi abnormal return pada periode pengamatan.

Pembahasan $\mathrm{H}_{3}$ (TVA sampel keseluruhan) Hasil pengujian menunjukan terdapat perbedaan trading volume activity sebelum dan sesudah pengumuman right issue. Hipotesis ini didukung oleh beberapa teori yaitu teori pasar efisien dan teori sinyal. Sinyal pengumuman right issue telah membuat pasar bereaksi ditandai dengan adanya perbedaan trading volume activity. 
I Gede Andika S Wibawa dan Ni Putu Santi Suryantini, Perbedaan Abnormal Return...

Trading volume activity (TVA) sebelum memiliki rata-rata sebesar 0,013108 dan trading volume activity (TVA) sesudah memiliki rata-rata sebesar 0,007664, hasil ini menunjukkan nilai TVA sebelum dan sesudah pengumuman right issue berpengaruh signifikan dibuktikan dari Asymp. Sig. (2-tailed) sebesar 0,009 dibawah nilai $\alpha=0,05$. Terdapat nilai rata - rata trading volume activity sesudah right issue yang lebih kecil dibandingkan sebelum right issue yang berarti terdapat penurunan jumlah volume perdagangan di pasar akan peristiwa right issue ini.

Beberapa penelitian mendapatkan hasil yang sama adalah Hermawan (2015) diperoleh perbedaan yang signifikan antara rata-rata trading volume activy sebelum dan sesudah pengumuman right issue, Yakup (2015) terdapat korelasi dan signifikan antara volume perdagangan saham sebelum right issue dengan sesudah right issue pada perusahaan yang tercatat di Bursa Efek Indonesia, dan Ridho (2017) diperoleh perbedaan pada volume perdagangan saham sebelum dan sesudah right issue.

Hasil penelitian ini dapat memberikan kontribusi implikasi teoritis sebagai berikut hasil penelitian ini menunjukkan bahwa pengumuman right issue tidak memberikan dampak signifikan pada abnormal return saham. Sesuai dengan signaling theory yang menyatakan bahwa pengumuman right issue mampu menjadi sinyal kepada pihak investor maupun calon investor akan adanya aksi korporasi right issue yang dilakukan oleh perusahaan, jika dirasa pengumuman tersebut tidak mengandung informasi yang penting maka pasar tidak akan bereaksi akan pengumuman tersebut. Sinyal dari pengumuman right issue yang 
diberikan oleh perusahaan ini telah cenderung tidak membuat pasar dan investor khususnya bereaksi. Investor disini mempertimbangkan alasan perusahaan dalam melaksanakan right issue, yang diukur berdasarkan abnormal return saham.

Hasil penelitian ini menunjukkan bahwa pengumuman right issue memberikan pengaruh yang signifikan negatif pada volume perdagangan saham. Ini berarti ketika terdapat pengumuman right issue maka terdapat penurunan volume perdagangan saham. Pengumuman right issue yang dilakukan perusahaan terbukti memiliki kandungan informasi, yang dapat dilihat dari adanya perubahan volume perdagangan saham yang merupakan bentuk dari reaksi investor atas suatu informasi yang dikeluarkan oleh perusahaan. Pengumuman right issue mampu menggambarkan keberagaman ekspetasi investor secara individual dalam pengambilan keputusan untuk berinvestasi, yang tercermin dari menurunnya volume perdagangan saham. Aktivitas volume perdagangan saham digunakan untuk melihat penilaian suatu info oleh investor individual dalam arti pengumuman right issue tersebut membuat suatu keputusan perdagangan atau tidak. Volume perdagangan yang menurun menunjukan investor yang sedikit atau kurang tertarik akan adanya aksi korporasi right issue yang dilakukan perusahaan dan peningkatan jumlah saham yang beredar namun tidak diimbangi dengan jumlah investor yang meningkat pula.

Implikasi kebijakan bagi perusahaan, perusahaan harus memiliki strategi untuk menarik minat investor saat melakukan aksi korporasi perusahaan right issue. Sehingga pengumuman right issue dapat memberikan sinyal positif bagi 
I Gede Andika S Wibawa dan Ni Putu Santi Suryantini, Perbedaan Abnormal Return...

perusahaan yang akan meningkatkan cumulative abnormal return dan meningkatkan jumlah volume perdagangan saham

Implikasi Kebijakan bagi Pemegang Saham Bagi pemegang saham penelitian ini dapat dijadikan rujukan atau referensi dalam pengambilan keputusan menggunakan haknya dalam right issue.

\section{SIMPULAN DAN SARAN}

Hasil pengujian hipotesis dan analisis yang telah diuraikan sebelumnya menghasilkan kesimpulan untuk sampel keseluruhan hari sebelum dan sesudah pengumuman right issue tidak didapatkan ada perbedaan abnormal return pada perusahaan emiten di BEI tahun 2016 dan 2017 untuk sampel secara keseluruhan. Hasil ini menunjukkan pengumuman right issue tidak memiliki dampak pada reaksi pasar dan abnormal return. Hal ini menunjukkan bahwa right issue yang dilakukan perusahaan dianggap tidak memiliki suatu informasi yang penting maka pasar tidak bereaksi akan adanya aksi korporasi right issue.

Untuk sampel pengelompokkan ukuran perusahaanhari sebelum dan sesudah pengumuman right issue tidak didapatkan ada perbedaan abnormal return pada perusahaan emiten di BEI periode 2016 dan 2017 untuk sampel yang dikelompokkan sesuai ukuran perusahaan. Hasil ini menunjukkan right issue tidak memiliki dampak terhadap abnormal return berdasarkan pengelompokan data menurut ukuran perusahaan.

Untuk perhitungan trading volume activity didapatkan perbedaan sebelum dan sesudah pengumuman right issue pada perusahaan-perusahaan di BEI periode 2016 dan 2017. Penurunan yang siginfikan dari trading volume activity setelah 
terjadinya right issue terlihat ini dapat terjadi karena tidak terdapatnya reaksi dari investor dan meningkatnya jumlah saham yang beredar di pasar saat right issue namun bertolak dengan penurunan jumlah investor yang menyebabkan harga saham dan trading volume activity menurun.

Berdasarkan kesimpulan yang telah dikemukakan, maka dapat diajukan saran-saran sehubungan dengan penelitian adalah untuk investor Penelitian selanjutnya Penelitian selanjutnya dapat meneliti kembali dengan melakukan pengelompokan data menurut sektor perusahaan, untuk mendapatkan hasil dari beberapa perusahaan yang bergerak di sektor yang sama. Bagi emiten diharapkan untuk Bagi emiten diharapkan untuk mempertimbangkan perencanaan yang matang dalam pelaksanaan right issue dan memberikan informasi yang jelas sehingga tidak terdapat asimetri informasi antara perusahaan dan investor. Tujuan penggunaan dana dari right issue juga menjadi pertimbangan dari investor, sebagai strategi peningkatan kinerja perusahaan.

\section{REFERENSI}

Agustin, S. (2017). Comparative Analysis Of Trading-Volume Activity And Abnormal return Before And After Stock split, International Journal of Scientific and Research Publications, 7(11), pp. 478-489.

Andayani, A. (2015). Pengaruh Kinerja Keuangan Dan Ukuran Perusahaan Terhadap Return Saham, Jurnal Ilmu \& Riset Akuntansi, 4(12), hal. 2-16.

Ang, R. (2001). Buku Pintar Pasar Modal Indonesia (The Intelligent Guide to Indonesian Capital market). Jakarta: Mediasoft Indonesia.

Anggaraini, N., dan Suprasto, H. B. (2015). Pengaruh Perataan Laba, Ukuran Perusahaan dan Debt to Equity Ratio Terhadap Reaksi Pasar Pada Perusahaan Manufaktur Di Bursa Efek Indonesia (BEI). Jurnal Akuntansi, 13(1), hal 45-62

Asmara, E. N. (2017). Pengaruh Karakteristik PerusahaanTerhadap Reaksi Pasar Modal : Studi Empiris Pada Perusahaan Yang Termasuk Dalam Indeks SRI-KEHATI Tahun 2009-2011, Jurnal EBBANK, 8(1), hal. 17-32. 
I Gede Andika S Wibawa dan Ni Putu Santi Suryantini, Perbedaan Abnormal Return...

Dewi, S., Wijana, I. N. dan Putra, A. (2013). Pengaruh Pengumuman Right issue Pada Abnormal return Dan Volume Perdagangan, E-Jurnal Akuntansi Universitas Udayana, 3, hal. 163-178.

Edirisinghe, U. C. and P. D. Nirmala. (2015). Stock Price Reaction To Announcements Of Right issues And Debenture Issues : Evidence From Colombo Stock Exchange, International Journal of Business and Social Research, 5(2), pp. 167-77.

Epriyeni, A. (2012). Pengaruh Pengumuman Merger, Akuisisi Dan Right Issue Terhadap Abnormal Return Saham Di Bursa Efek Indonesia, E-Jurnal Akuntansi STIE MDP, hal. 1-7.

Hartono, J. (2015). Teori Portofolio Dan Analisis Investasi Edisi 10. .Yogyakarta: BPFE Yogyakarta.

Hermawan, T. (2015).Analisis Perbedaan Abnormal return, Trading volume activity Dan Bid Ask Spread Sebelum Dan Sesudah Pengumuman Right issue ( Studi Kasus Perusahaan Indek Saham Syariah Indonesia ( ISSI ) yang Terdaftar pada BEI Tahun 2011-2013, Jurnal Dinamika Manajemen.

Hendrianto, S. (2015). Analisis Cash Ratio, Det To Equity Ratio, Return On Asset, Growth, Dan Pengaruhnya Terhadap Dividend Payout Ratio Pada Perusahaan Pertambangan Yang Terdaftar Di Bursa Efek Indonesia, Jurnal Tekun, VI(1), pp. 112-127.

Jayanti, F. A. (2014). Analysis Of The Difference Among Abnormal return, Trading volume activity And Security Return Variability Before And After Right issue Announcement (Study Of Listed Comapanies In Indonesian Stock Exchange Periode 2010- 2012, E-Jurnal Telkom University, 1(3), pp. 106-121.

Kabir, R. and P. Roosenboom . (2012). Can the stock market anticipate future operating performance? Evidence from equity rights issues, Journal Financial Management.

Kithinji, J. G., W. Oluoch. and R. Mugo. (2014). What Is The Effect Of Rights Issue On Firms Share Performance In The Nairobi Securities Exchange?, Research Journal Of Finance And Accounting, 5(4), pp. 76-84.

Magdalena, N. dan Abdul, M. A. (2004). Pengujian Stabilitas Struktural Pengaruh Harga Saham, Return Saham, Varian Return Saham Dan Volume Perdagangan Terhadap Bidask Spread Pra Dan Pasca Laporan Keuangan. Jurnal Empirika. 17(1), hal. 40-49.

Mohanty, P. and Agarwal A. (2012). The Impact of rights issue on stock returns in India, Asia-Pacific Finance and Accounting Review , 1(1), hal. 5-16.

Munawaroh (2013). Profitabilitas Terhadap Nilai Perusahaan Pada PerusahaanPerusahaan LQ-45, Artikel Ilmiah, hal. 1-13. 
Nasution, Y. S. J. (2015). Hypothesis Pasar Efisien / Efficient Market Hypothesis ( Pasal Modal Menurut Teori Fama Dan Pandangan Islam ), Jurnal Perspektif Ekonomi Darussalam, 1(1), hal. 25-43.

Omran, M and Eric, G. (2009). On The Relationship Between Trading Volume And Stock Price Volatility In Case. International Journal Of Managerial Finance. New York. 5(1) pp. $110-134$

Otieno, O. D. (2015). The Effects Of Rights Issue Announcements On Stock Returns For Firms Listed At The Nairobi Securities Exchange, International Journal Of Education And Research, 3(9), hal. 411-426.

Pratama, I. G. S. (2015). Analisis Perbandingan Abnormal return Saham Sebelum Dan Sesudah Pengumuman Right issue, Bali: E-Jurnal Akuntansi Universitas Udayana, 1(I), hal. 243-257.

Putri, Desya , Maslichah, D. C. M. (2016). Analisis Reaksi Investor Terhadap Pengumuman Right issue Di Bursa Efek Indonesia, Jurnal Universitas Islam Malang hal. 121-131.

Ridho, A. (2017). Analisis Reaksi Investor Terhadap Pengumuman Right issue Di Bursa Efek Indonesia, E-Journal Proceeding of Management, 4(3), hal.2562-2569.

Republik Indonesia, (1995). Undang - Undang No 8 Tahun 1995 Tentang Pasar Modal

Rusnanda, E. W. dan Pardi. (2013). Analisa Pengaruh Pengumuman Merger Dan Akuisisi Terhadap Abnormal return Saham Bank Umum di Bursa Efek Indonesia, Jurnal Graduasi,1(2), hal. 89-101.

Samsul, Mohamad. (2006). Pasar Modal Dan Manajemen Portofolio. Surabaya: Erlangga.

Silviyani, N. L. N. T., Sujana, E. dan I. M. P Adiputra. (2014). Kapitalisasi Pasar Terhadap Return Saham Perusahaan Yang Berada Pada Indeks LQ45 Di Bursa Efek Indonesia Periode Tahun 2009-2013 ( Studi Empiris Pada Perusahaan Lq45 Di Bursa Efek Indonesia), E-Journal S1 Ak Universitas Pendidikan Ganesha Jurusan Akuntansi Program S1, 2(1), hal. 1-11

Sugiyono. (2016). Metode Penelitian Administrasi. Bandung: Penerbit Alfabeta.

Tandelilin, E. (2010). Portofolio Dan Investasi. Yogyakarta: Kanisius.

Umesh, N. P., P. P. Parab and Y. V. Reddy. (2016). Impact of Stock split Announcements on Stock Prices and Liquidity: Empirical Evidence from India', An International Journal of Management Studies, 6(4). doi: 10.11127/gmt.2016.12.05.

Yakup, W. Y. and Cahyadi, Y. (2015). Analisis Pergerakan Harga Saham Dan Volume Perdagangan Saham Terhadap Pengumuman Right issue Pada 
I Gede Andika S Wibawa dan Ni Putu Santi Suryantini, Perbedaan Abnormal Return...

Emiten Di Bursa Efek Indonesia', e-journal S1 Universitas Bima Nusantara.

Zaqi, Mochamad. (2006). Reaksi Pasar Modal Indonesia Terhadap PeristiwaPeristiwa Ekonomi Dan Peristiwa-Peristiwa Sosial-Politik Dalam Negeri (Studi Pada Saham LQ45 Di Bej Periode 1999-2003). Tesis Pascasarjana Program Studi Magister Manajemen Pada Fakultas Ekonomi Universitas Diponegoro, Semarang. 